\title{
Listy Zygmunta Kukulskiego z okresu szkockiego źródłem badań biograficznych
}

\section{Letters by Zygmunt Kukulski from the Scottish Period as a Source of Biographical Research}

Zygmunt Bolesław Kukulski (ur. 2 maja 1810 r. w Jaśle, zm. 4 grudnia 1944 r. w Peebles, Szkocja) wychował się i pobierał pierwsze nauki w rodzinnym mieście, Jaśle ${ }^{1}$. Następnie w 1909 r. w Krakowie rozpoczął nowy etap życia i edukacji. Był to czas studiów na Wydziale Prawa Uniwersytetu Jagiellońskiego. Jednak w roku akademickim 1910/1911 zdecydował przenieść się na Wydział Filozoficzny, na którym studiował polonistykę. Po zakończeniu studiów (1913) rozpoczął praktykę w Gimnazjum św. Anny w Krakowie. Ukończenie pierwszego roku praktyki zawodowej zbiegło się w wybuchem pierwszej wojny światowej. Ważnym wydarzeniem, którego skutki miały wpływ na całe dalsze życie Kukulskiego, było powołanie go do wojska ${ }^{2}$ i udział w bitwie pod Rokitą, w wyniku której został ranny

* Katarzyna Wołk - dr, adiunkt w Instytucie Pedagogiki Uniwersytetu Marii Curie-Skłodowskiej w Lublinie, katarzyna.wolk2016@gmail.com. w nogę, a następnie wzięty do niewoli rosyjskiej. Ciąg nieszczęśliwych wydarzeń spowodował, że Kukulski wrócił do Krakowa w 1917 r. jako inwalida wojenny. Kolejne operacje nie uratowały nogi Kukulskiego ${ }^{3}$. Ból i cierpienie nie przeszkodziły mu w przygotowaniach do obrony napisanej pod kierunkiem Ignacego Chrzanowskiego rozprawy doktorskiej pt. „Działalność pedagogiczna Tadeusza Czackiego", która odbyła się

1 J. Starnawski, Sylwetki lubelskich humanistów XIX i pierwszej połowy XX w., Lublin 2004, s. 66.

2 Wybuch pierwszej wojny światowej spowodował, że do wojska zostało powołanych wielu uczniów, studentów, a nawet profesorów. Zygmunt B. Kukulski został wcielony do armii austriackiej w stopniu porucznika rezerwy 31 lipca $1914 \mathrm{r}$. Walczył na froncie rosyjskim w 3. Tyrolskim Pułku Strzelców Cesarskich. Został ranny w nogę 13 czerwca 1915 r., $\mathrm{w}$ dniu bitwy polskich legionistów pod Rokitą w okolicy Zaleszczyk; M. Wieliczko, Zygmunt Bolesław Kukulski (2 maja 1890-4 grudnia 1944), „Rocznik Jasielski", 5 (2003) s. 103-106.

3 Tamże. 
14 grudnia 1917 r. na Uniwersytecie Jagiellońskim. Po uzyskaniu stopnia doktora filozofii kontynuował studia na Wydziale Prawa UJ, ale nie ukończył ich.

Przed pierwszą wojną światową istniały na ziemiach polskich tylko cztery uniwersytety, a wielu uczonych pracowało w wyższych uczelniach nie tylko Rosji, ale także państw Europy Zachodniej i Stanów Zjednoczonych. Po odzy-

4 J. Starnawski, Sylwetki lubelskich humanistów XIX i pierwszej połowy X w., s. 59; J. Draus, Zygmunt Kukulski (1890-1944), „Historia Wychowania i Opieki" 2(17) (1989) s. 8.

5 Pierwsza Katedra pedagogiki powstała na Uniwersytecie w Poznaniu, natomiast druga na Uniwersytecie Lubelskim; R. Skrzyniarz, Dzieje pedagogiki na Katolickim Uniwersytecie Lubelskim Jana Pawła II, w: Pedagogika na Katolickim Uniwersytecie Lubelskim Jana Pawła II. Historia i wspótczesność, red. A. Rynio, R. Skrzyniarz, współpraca Ł. Badeńska, Lublin 2011, s. 13-14, przypis 2. Należy jednak pamiętać, że pierwszym ośrodkiem naukowym, w którym rozpoczęto uprawiać pedagogikę jako naukę, był Katolicki Uniwersytet Lubelski, a jedną z osób tworzących jej strukturę był dr Zygmunt Kukulski.

6 Kazimierz Twardowski (1866-1938), stworzył czołową polską szkołę filozoficzną, tzw. szkołę lwowsko-warszawską. Należał do najbardziej zasłużonych polskich pedagogów oraz organizatorów nauki i szkolnictwa; przyczynił się do utworzenia we Lwowie pierwszego polskiego pełnego gimnazjum żeńskiego (1896-1898); jako rektor Uniwersytetu Lwowskiego walczył z władzami austriackimi o utrzymanie statusu uczelni polskiej i zabiegał o zachowanie ciągłości pracy uniwersyteckiej podczas wojny; A. Śródka, P. Szczawiński, Biogramy uczonych polskich, z. 3: P-Z, Wrocław-Warszawa-Kraków-Gdańsk-Łódź 1985, s. 445-450.

7 Uniwersytet Jana Kazimierza we Lwowie, sygn. Zygmunt Kukulski nr 999, zespół 26, opis 5, Wydział Humanistyczny Uniwersytetu Jana Kazimierza we Lwowie, 30 czerwca 1925, nr 186. Przedmiot: Udzielenie veniae legendi z zakresu pedagogiki Drowi Zygmuntowi Kukulskiemu. skaniu niepodległości w Polsce brakowało wykształconej kadry naukowej, mogącej prowadzić zajęcia na nowo powstałym Uniwersytecie Lubelskim. Kukulski za namową swojego nauczyciela akademickiego - Ignacego Chrzanowskiego 28 kwietnia 1919 r. aplikował na stanowisko zastępcy profesora pedagogiki do katedry, która została dla niego utworzona i rozpoczęła działalność w październiku 1920 roku4. Była to druga katedra pedagogiki w Polsce ${ }^{5}$. W celu pełnienia tej funkcji Kukulski musiał przeprowadzić się z Krakowa do Lublina. Uniwersytet Lubelski nie był jedynym ośrodkiem naukowym, z którym Kukulski związał się $\mathrm{w}$ tym czasie. Znaczącą rolę w jego karierze naukowej odegrał Kazimierz Twardowski ${ }^{6}$, za namową którego złożył habilitację na Uniwersytecie Jana Kazimierza we Lwowie. Kukulski otrzymał habilitację 25 czerwca $1925 \mathrm{roku}^{7}$. Pracował w szkołach średnich Lublina, m.in. w Gimnazjum im. Stanisława Staszica (1930-1936) oraz Szkole Lubelskiej (1936-1939), prowadził zajęcia na uniwersytecie, pisał prace naukowe i wydawał źró- 
dła do historii szkolnictwa w Polsce. Ponadto wiele czasu poświęcał na działalność kulturalno-społeczną ${ }^{8}$.

W 1939 r. Kukulski jako reprezentant środowiska naukowego z ramienia Katolickiego Uniwersytetu Lubelskiego został oddelegowany na światową wystawę do Chicago. Wybuch wojny polsko-niemieckiej we wrześniu 1939 r. uniemożliwił mu powrót do kraju. Statek, którym płynął Kukulski, musiał przybić do brzegów Wielkiej Brytanii. Pobyt Kukulskiego na terytorium imperium brytyjskiego, najpierw na terenie Anglii, a później na ziemiach szkockich nie został dotychczas przebadany ${ }^{9}$. Pewne informacje na ten temat przekazuje Jan Draus $\mathrm{w}$ artykule pt. Zygmunt Kukulski $(1890-1944)^{10}$. Autor powołuje się m.in. na Księgę kasową Funduszu Kultury Narodowej oraz sprawozdania z działalności Urzędu Oświaty i Spraw Szkolnych za 1941 r., które znajdują się w Archiwum Instytutu Polskiego i Muzeum im. gen. W. Sikorskiego w Londynie. W literaturze nie znajdujemy opisu życia i działalności Kukulskiego na obczyźnie. Informacje, które docierały do Polski, były zdawkowe i nie do końca rzetelne. Świadczą o tym chociażby rozbieżności dotyczące podawanej daty śmierci profesora. Bardziej szczegółowy opis sytuacji życiowej profesora Zygmunta Kukulskiego w czasie pobytu na emigracji oraz próba odtworzenia jego losów zostały przedstawione w rozprawie doktorskiej autorstwa Katarzyny Kosackiej [Wołk] ${ }^{11}$.

8 Zygmunt Kukulski prowadził działalność społeczną w organizacjach akademickich (praca w Kole Pedagogicznym studentów KUL - organizowanie zebrań referatowo-dyskusyjnych oraz utworzenie biblioteki Koła Pedagogicznego, mająca na celu wsparcie jego członków pod kątem naukowym, działalność w Wojewódzkiej Komisji Pomocy Młodzieży Akademickiej), organizacjach społecznych (zawiązanie Komitetu Obchodu 150-tej rocznicy ustanowienia Komisji Edukacji Narodowej i śmierci ks. Stanisława Konarskiego, działalność w: Komitecie Obchodu Setnej rocznicy Zgonu Stanisława Staszica w Lublinie, Komitecie Budowy Pomnika Jana Kochanowskiego), organizacjach naukowo-kulturowych (Towarzystwo Przyjaciół Nauk, Towarzystwo Naukowe KUL, Lubelskie Towarzystwo Miłośników Książki); K. Kosacka [Wołk], Zygmunt Boleslaw Kukulski (1890-1944) pedagog, wychowawca i społecznik, Lublin 2016, praca doktorska napisana na Wydziale Nauk Społecznych Katolickiego Uniwersytetu Lubelskiego Jana Pawła II w Lublinie pod kierunkiem dra hab. R. Skrzyniarza, prof. KUL, mps, s. 120-136.

9 O pobycie Kukulskiego na emigracji w swoich publikacjach wspominają także m.in. Jan Dobrzański, (Wspomnienie o Zygmuncie Kukulskim, „Rocznik Humanistyczny, 2/3 [1950/1951] s. 357-365), Jan Draus (Zygmunt Kukulski [1890-1944]), Mieczysław Wieliczko (Zygmunt Bolesław Kukulski), Edward Walewander (Pedagogika uniwersytetu w życiu i działalności naukowej Zygmunta Bolesława Kukulskiego, w: Wczoraj dziś i jutro pedagogiki uniwersyteckiej w świetle twórczości Stefana Kunowskiego, red. K. Braun, M. Łobacz, A. Rynio, Lublin 2010, s. 53-69).

10 J. Draus, Zygmunt Kukulski (1890-1944), s. 5-19.

11 K. Kosacka [Wołk], Zygmunt Bolesław Kukulski (1890-1944). 
Główne źródło informacji o życiu i działalności Kukulskiego stanowią listy własnoręcznie pisane przez profesora do profesora Jana Hulewicza ${ }^{12}$. Listy, jako materiały własne ${ }^{13}$, stanowią ciekawe źródło do badań biograficznych, gdyż ukazują „utrwalone i zachowane ślady myśli, działań, życia człowieka oraz jego środowiska, które umożliwiają odtwarzanie interesujących przejawów życia społecznego w przyszłości"14.

Prywatna korespondencja Kukulskiego znajduje się w Archiwum Instytutu Polskiego i Muzeum im. gen. Sikorskiego w Londynie (The Polish Institute and Sikorski Museum). Listy zostały zebrane w jednej teczce opatrzonej sygnaturą A. 19.II/31. Jest to jedyne miejsce, w którym można znaleźć własnoręcznie napisane listy Zygmunta Kukulskiego. Jego pismo jest bardzo drobne i trudne do rozczytania, zwłaszcza dla współczesnego czytelnika. W listach nie znajdujemy skreśleń czy poprawek, nie mamy więc pewności, czy były one przepisywane z brudnopisów, czy Kukulski bardzo dokładnie zastanawiał się nad każdym napisanym słowem i zdaniem. Język, który używał autor, był współczesny dla jego czasów - okresu drugiej wojny światowej. Do tej pory korespondencja nie była szczegółowo analizowana i cytowana.

Korespondencja pochodząca z lat czterdziestych XIX wieku dotyczy głównie przyznania Kukulskiemu zasiłku na życie i działalność naukową. Z listów można

12 Jan Hulewicz (1907-1980), historyk wychowania, dr filozofii uniwersytetu we Lwowie, zarządzał Funduszem Kultury Narodowej od lipca 1940 r., funkcję przejął po profesorze Kazimierzu Wodzickim.

13 Materiały własne stanowią listy, notatki, materiały, które zostały pozostawione przez osobę, której życiorys jest badany. Do materiałów cudzych należy zaliczyć wspomnienia, akta osobowe; G. Michalski, Źródła bo badań biograficznych $w$ historii wychowania, w: Konteksty i metody $w$ badaniach historyczno-pedagogicznych, red. T. Jałmużna, I. Michalska, G. Michalski, Kraków 2004, s. 174.

14 T. Buksiński, Zasady i metody interpretacji tekstów źródłowych, Poznań 1991, s. 12; D. Lalak, A. Ostaszewska, Źródła do badań biograficznych. Listy dzienniki - pamiętniki - blogi - materiały wizualne, Warszawa 2016, s. 19-56.

15 IPimS, sygn. A.19.II/31, List prof. Kukulskiego, 7 grudnia 1940. również dowiedzieć się, że funkcjonowanie i przemieszczanie się Kukulskiego było utrudnione ze względu na chorą nogę. Mimo to profesor starał się aktywnie uczestniczyć w życiu Polonii znajdującej się w Wielkiej Brytanii, prowadził badania, odwiedzał ważniejsze z jego punktu widzenia ośrodki edukacyjne. W listach zwracał się o udzielenie "«glejtu» umożliwiającego swobodne poruszanie się zwłaszcza w tzw. «Protected Arens»"15. Prośby motywował swoją trudną sytuacją materialną oraz mieszkaniową. Opisywał także plany naukowe, na które potrzebował funduszy. W celu pozy- 
skania środków próbował spotkać się z profesorem Stanisławem Kotem ${ }^{16}$. Jednak w wyniku swoich wcześniejszych planów nie mógł stawić się we wskazanym terminie. Kukulski czuł się zobowiązany wyjaśnić tę sytuację, przedstawiając w korespondencji swoją krótką historię, co okazało się kluczową informacją do ustalenia losów Kukulskiego. Listy te są nie tylko rzetelnym i bogatym źródłem do badań biografii Kukulskiego, na ich podstawie możemy opisywać życie Kukulskiego na obczyźnie, analizować jego dokonania społeczne i okoliczności powstania artykułów dotyczących pedagogiki porównawczej. Bez wątpienia stanowią także źródło do dalszych badaniach biograficznych.

16 Stanisław Kot (1885-1975), polski historyk, działacz ruchu ludowego, wychowawca. We wrześniu $1939 \mathrm{r}$. znalazł się na emigracji i wszedł jako wicepremier do rządu gen. Władysława Sikorskiego. W latach 1941-1942 był ambasadorem rządu RP na uchodźstwie w Związku Swieckim. 
Peebles, 1 października 1940 r.

Szanowny Panie Profesorze,

Uprzejmie zawiadamiam, iż z powodu nieszczęśliwych dla mnie zwrotów bytowania (proteza i lokacja mieszkania) zmieniłem czasowo miejsce zamieszkania.

Dziękuję najuprzejmiej za nadesłanie polecenia i rekomendację do British Musem co mi się może przydać w przyszłości).

Z prof. Kotem nie mogłem się żadną miarą skontaktować, a jego sekretarz cz. W. oświadczył dn. 13 ub. m. , że prof. Kot obecnie nikogo nie przyjmuje i wyjeżdża na pewien czas.

W czasie kiedy mój koniecznością podyktowany wyjazd był całkowicie opracowany, zaproponował mi prof. Jedlicki pełniący funkcję nacz. Wydziału przy Ministerstwie Generała Broni Hellera, dyrekcją Gimnazjum i Liceum w Ealing. Z propozycji tej trudno mi było skorzystać , podczas gdym był zmuszony towarzyszącymi okolicznościami do uprzedniej samodzielnej decyzji.

Czekałem na ten rodzaj pracy w ciągu lipca i sierpnia. A kiedy się wtedy beze mnie obeszło, postanowiłem iść własną samodzielną decyzją, jak zwykłem i dotychczas.

Gdyby atoli ten posterunek pracy wymagał koniecznie mojej osoby, mógłbym mimo wszystko postawić się do dyspozycji w każdej chwili, choć z drugiej strony po latach wyczerpującej pracy w wielu dziedzinach chciałbym znów pogłębić swą wiedzę fachową.

Łączę wyrazy prawdziwego szacunku i poważania.

Zygmunt Kukulski

12, Edinburgh Road

Peebles

N. BR.

Źródło: IPiMs, sygn. A.19.II/31, List prof. Kukulskiego z dn. 01.10.1940 r. 
N.B. Peebles, 29 października 1940 r.

12, Edniburgh Road

Szanowny Panie Profesorze!

Dziękuję najuprzejmiej za list i przesłany zasiłek z F.N. K., na który załączam kwit, sporządzony przeze mnie, gdyż przy piśmie nie było żadnego formularza.

Nie znając adresu bliższego prof. Kota ośmielam się za łaskawym pośrednictwem Państwa złożyć. im serdeczne słowa podzięki za pamięć o mnie i wyrazić szery żal z powodu niemożności zobaczenia się z Nim przed moim wyjazdem.

Co się zaś tyczy proponowanego stałego miesięcznego zasiłku w kwocie 10,to chętnie go zamienię na dotychczasową pomoc miesieczną w formie $Ł 6.4$ z Polish Relief Fund'n i Ł 3 z naszego Komitetu Generalnego, która to suma stanowiła jedyną podstawę obecnej mojej egzystencji.

Łączę wyrazy prawdziwego szacunku i poważania

Zygmunt Kukulski

Załącznik $1^{1}$.

Źródło: IPiMS, sygn. A.19.II/31, List prof. Kukulskiego z dn. 29.10.1940 r.

1 Załącznika nie drukujemy. 
12, Edinburgh Road,

Peebles, N. B.

7. XII.1940.

Wielce Szanowny Panie Profesorze i Ministrowie!

Najuprzejmiej dziękuję za łaskawe zainteresowanie się moją osobą za pośrednictwem ks. Prof. Wodickiego i Hulewicza i przyznanie mi z F.K.N jednorocznego zasiłku w wysokości Ł 20, a następnie stałego zasiłku miesięcznego Ł. 10 co spowodowało zrzeczenie się z mojej strony jeszcze z końcem października otrzymywanej z naszego Generalnego Konsulatu w Londynie miesięcznej pomocy Ł. 3 oraz z początkiem b. m. zasiłku pobieranego z Polish Relief Found’n w wysokości Ł 6.47.4 miesięcznie. Mutatis mutandis, układ pozostał ten sam, wolę jednak pomoc w obecnej formie, co mam do zawdzięczenia W. Sz. P. Profesorowi. Przed wyjazdem z Londynu chciałem zobaczyć się z P. Profesorem, jednakowoż mój znajomy inżynier, który w tej sprawie porozumiewał się z sekretarzem koło połowy września otrzymał stanowczą odpowiedź, że widzenie się możliwe będzie dopiero za tydzień. Na ten termin nie mogłem się stawić z powodu ustalonego już przedtem dnia mego wyjazdu. Dalsze moje milczenie wytłumaczy krótka historia mojego losu.

Z dniem od 2 do 22 sierpnia ub. R. byłem z wycieczką Pol. Akad. Związku Zbliżenia Międzynarodowego „Liga” w Stanach Zjedn[oczonych] A[meryki] P[ółnocnej], gdzie wśród Polonii wygłosiłem kilkanaście prelekcji w New Yourku, Philadelphia, Baltimore, Washington, Pittberga, /Chicago i Buffalo. Oczywiście, że i zwiedzanie wystawy światowej w Nowym Yorku było jednym z punktów naszego programu.

Dnia 1 września ub. r. mieliśmy być z powrotem w Gdyni. Wybuch wojny skierował „Piłsudskiego” do wybrzeży Północnej Brytanii. Po wylądowaniu w październiku ub. r. spędziłem z pasażerami kilka miesięcy w Sunderlandzie (Półn. Anglia) a następnie uzyskałem zezwolenie na wyjazd do Londynu dla spraw protezowych, co mi uskuteczniono po dłuższym staraniu w sierpniu b. r. w kwietniu wniosłem przez Paryż podanie do British Council o stypendium bez odpowiedzi do dnia dzisiejszego.

Pod koniec lipca zwiedziłem zawiązek Naszego gimnazjum w Ealing, w tej myśli że może się będę mógł przydać, ale o moją pomoc zgłoszono się dopiero we wrześniu, kiedy znajdując się w nader uciążliwych warunkach bytu ze względu na protezowaną nogę i brak odpowiedniego mieszkania postanowiłem skorzystać z wyrobionego mi przeniesienia aby sobie na własną rękę, bez oglądania się na stypendia i posady urządzić warsztat pracy i wyzyskać pobyt 
tutejszy dla przygotowania się do pracy we własnym kraju. W ten sposób znalazłem się od dwóch miesięcy w Peebles, które okazało się dla mnie kurortem ze względu na swoje centralne położenie. Przedtem jeszcze udało mi się „psim swendem" zobaczyć pobieżnie Oxford, Cambridge, Eton Collage, Harrow School, później Edinburgh, Glesgow, Aberdeen. Teraz planuję systematyczną robotę: możliwie dokładne przyjrzenie się pracy brytyjskiego szkolnictwa od szkół powszechnych i przedszkoli przez średnie do akademickich. Zmówiłem się z p. Branderem, sekretarzem Uniwersytu Burenn, który mi przesłał Yearbook, ściągam programy studiów z różnych uniwersytetów, rozpocząłem wizytowanie miejscowości różnych szkół, mając na widoku w przyszłości i dalsze okręgi. Jestem już w kontakcie z „Educational Institute of Scotland”, skąd będę mógł wypożyczać potrzebne mi książki drogą pocztową. Uzyskałem już zaproszenie do zwiedzenia dobrej i starej grupy prywatnych szkół średnich t. zw. Merchant Company School w Edinburgh. Nawiązywanie stosunków przychodzi mi z łatwością, oby tylko ośrodki zezwoliły mi uzyskanie możliwości. Zresztą jestem wyznawcą zasady: Chcieć to móc. Jedno mi się jeszcze snuje po głowie: umieścić kilka artykułów do pracy na temat naszego wychowania i przodowniczych w tej dziedzinie myśli i urządzeń. Sądzę, że i to uda mi się uskutecznić za jaki kwartał.

Oto garść moich poczynań skromnych... Tuszę, że powyższe zwierzenia tłumaczą moje zacięcie zębów i chwilowe milczenie. Państwa pamięć ujęła mnie i zniewoliła do podzielenia się tymi drobnymi i bądź co bądź blachami wiadomościami w obliczu wielkich wydarzeń dziejowych, które przy pomocy istotnie potężnej W. Brytanii i współpracy obecnych naszych Mężów Stanu w oparciu o naszą armię doprowadzą niewątpliwie do odbudowania silnej i mądrze rządzonej wolnej Ojczyzny.

Łączę wyrazy prawdziwego szacunku i poważania.

Zygmunt Kukulski

P.s. Mam jedno zapytanie i prośbę, a mianowicie czy nie można by uzyskać od Nowego Roku coś w rodzaju „glejtu” umożliwiającego swobodne poruszanie się zwłaszcza w t. zw. „Protected Arens”. Starania bowiem w różnych urzędach policyjnych o pozwolenie na każdorazowy wyjazd zabierają dużo czasu i wymagają ustawicznego pisania co niepomierne utrudnia zamierzoną moją pracę w różnych terenach, zwłaszcza że dochodzi do tego i korespondencja ze szkołami. Za jakiekolwiek utrudnienia pod tym względem niezmiernie wdzięczny.

$\mathrm{ZK}$

Źródło: IPiMS, sygn. A.19.II/31, List prof. Kukulskiego z dn. 07.12.1940 r. 
12 Edinburgh Road

Peebles, N. B.

Dnia, 23 grudnia 1940.

\section{Szanowny Panie Profesorze!}

W związku z pismem z dn. 19 b. m. L. dz. 676/40 przesyłam w załączniku z podziękowaniem pokwitowanie na odbiór Ł 10,- z t. zw. „Funduszu amerykańskiego", które to zawsze bardzo się przyda na zakup niektórych potrzebnych mi książek, zwłaszcza że organizuje sobie w obecnym miejscu pobytu możliwy warsztat pracy po wejściu w kontakt z różnymi władzami szkolnymi i edukacyjnymi oraz z biblioteką pedagogiczną głównie w Edynburgu (1,1/2 g. autobusem,) oraz w Glesgow. Mam nawet opracowany plan wypadów do celniejszych szkół szkockich, a może i niektórych angielskich po przeprowadzonej już z nimi odpowiedniej korespondencji.

Łączę wyrazy prawdziwego szacunku oraz życzenia Noworoczne.

Zygmunt Kukulski

Zał. $1^{2}$.

Źródło: IPiMs, sygn. A.19.II/31, List prof. Kukulskiego z dn. 23.12.1940 r.

2 Załącznika nie drukujemy. 


\section{Bibliografia}

Buksiński T., Zasady i metody interpretacji tekstów źródłowych, Poznań 1991. Dobrzański J., Wspomnienie o Zygmuncie Kukulskim, „Rocznik Humanistyczny, 2/3 (1950/1951) s. 357-365.

Draus J., Zygmunt Kukulski (1890-1944), „Historia Wychowania i Opieki”, 2(17) (1989).

Kosacka K. [Wołk], Zygmunt Boleslaw Kukulski (1890-1944) - pedagog, wychowawca i społecznik, Lublin 2016, praca doktorska napisana na Wydziale Pedagogiki Katolickiego Uniwersytetu Lubelskiego Jana Pawła II w Lublinie pod kierunkiem dra hab. R. Skrzyniarza, prof. KUL, mps.

Lalak D., Ostaszewska A., Źródła do badań biograficznych. Listy - dzienniki pamiętniki - blogi - materiały wizualne, Warszawa 2016.

Michalski G., Źródła bo badań biograficznych w historii wychowania, w: Konteksty i metody $w$ badaniach historyczno-pedagogicznych, red. T. Jałmużna, I. Michalska, G. Michalski, Kraków 2004.

Skrzyniarz R., Dzieje pedagogiki na Katolickim Uniwersytecie Lubelskim Jana Pawła II, w: Pedagogika na Katolickim Uniwersytecie Lubelskim Jana Pawła II. Historia i współczesność, red. A. Rynio, R. Skrzyniarz, współpraca Ł. Badeńska, Lublin 2011.

Starnawski J., Sylwetki lubelskich humanistów XIX i pierwszej połowy XX w., Lublin 2004.

Śródka A., P. Szczawiński, Biogramy uczonych polskich, z. 3: P-Z, Wrocław-Warszawa-Kraków-Gdańsk-Łódź 1985.

Walewander E., Pedagogika uniwersytetu w życiu i działalności naukowej Zygmunta Bolesława Kukulskiego, w: Wczoraj dziś i jutro pedagogiki uniwersyteckiej w świetle twórczości Stefana Kunowskiego, red. K. Braun, M. Łobacz, A. Rynio, Lublin 2010, s. 53-69.

Wieliczko M., Zygmunt Bolesław Kukulski (2 maja 1890-4 grudnia 1944), „Rocznik Jasielski", 5 (2003). 